\title{
Operatīvās darbības likuma 4. pantā lietotā jēdziena "kūdīt" atbilstība regulējuma mērķim
}

\author{
Mg. iur. Märcis Grinciuns \\ Rīgas Stradiña universitāte, Juridiskā fakultāte, Latvija \\ marcis_g@outlook.com
}

\section{Kopsavilkums}

Operatīvās darbības likuma (ODL) 4. pantā noteikti operatīvās darbības principi, kuri jāievēro operatīvās darbības pasākumu plānošanas un izpildes gaitā. Principā, kurš ietverts ODL 4. panta otrajā dạ̦ā, paredzēts personas kūdīšanas uz noziedzīgu rīcību aizliegums. Šis aizliegums ir attiecināms arī uz ODL 15. panta trešajā dalāa noteiktā operatīvā eksperimenta veida (turpmāk šajā rakstā, runājot par operatīvo eksperimentu ODL 15. panta trešās daḷas izpratnē, - operatīvais eksperiments) norisi, kuras gaitā pasākuma veicējs, kontaktējoties ar personām, attiecībā uz kurām tiek veikta operatīvā izstrāde, var tās uzkūdīt (pamudināt) veikt noziedzīgas darbības. Šāda operatīvā eksperimenta veicēja aktivitāte ir prettiesiska, un tas ir apliecināts gan Latvijas Republikas Augstākās tiesas, gan Eiropas Cilvēktiesību tiesas spriedumos.

Personas uzkūdī̌̌ana (pamudināšana) veikt noziegumu ir tikai viens no vairākiem operatīvā eksperimenta prettiesiskās izpausmes veidiem. Personu uz nozieguma veikšanu var ne tikai uzkūdīt, bet arī provocēt. Iepriekš veiktajā pētỉjumā secināju, ka jēdziens "kūdìt" ODL 4. panta otrajā dạ̦ā lietots neprecīzi un šì panta formulējums jāpilnveido [11, 51].

Šajā rakstā, kopsakarā ar konstatētajiem operatīvā eksperimenta pārkāpumiem praksē, tiek analizēta ODL 4. pantā lietotā jēdziena "kūdīt" atbilstība regulējuma mērḳim.

Atslēgvārdi: operatīvā darbība, operatīvais pasākums, operatīvās darbības principi, operatīvais eksperiments, kontrolpirkums, kūdīšana, provokācija.

\section{levads}

Tiesību normas regulējumam jābūt formulētam tā, lai tas būtu skaidrs, nepārprotams un vienlaikus tiktāl abstrakts, lai norma būtu piemērojama visā regulētā jautājuma 
izpausmes spektrā. Normā izmantotajiem terminiem jāatbilst regulējuma mērḳim, citādi norma var tikt nepareizi interpretēta un arī piemērota.

Valsts kancelejas Normatīvo aktu projektu izstrādes rokasgrāmatā teikts, ka sekmīgai tiesību normu piemērošanai normatīvajos aktos nepieciešama skaidra, viegli uztverama izteiksme ar jēdzieniski nepārprotamiem terminiem, kas valodas lietojumā nostabilizējušies noteiktā nozīmē $[18,93]$.

Novērots, ka likumdevējs likuma ietvaros mēdz skaidrot normatīvajā aktā izmantoto terminu nozīmi. To izpratne var atšḳirties no skaidrojumiem terminu vārdnīcās, bet reizēm skaidrojums ir nepieciešams, lai noteiktu likuma darbības robežas. Rakstā pētìtā jēdziena "kūdìt" definējuma ODL normās nav, tādēḷ tā nozīme saprotama tikai no principa vārdiskā satura.

Juridiskajā literatūrā jēdziens "kūdīt" tiek skaidrots kā fiziska vai psihiska personas ietekmēšana, kas vērsta uz to, lai citā personā radìtu apņemšanos izdarīt noziedzīgu nodarījumu vai piedalīties tajā [13, 119]. Savukārt Latviešu literārās valodas vārdnīcā jēdziens "kūdīt" aprakstīts kā "rosināt, mudināt uz kādu (parasti neatḷautu, negodīgu) rīcību” [15, 461]. No jēdzienu skaidrojumiem saprotams, ka kūdīšana izpaužas situācijā, kad viena persona (kūdītājs) aktīvi iespaido otru personu veikt noziedzīgas darbības. Taču, vērtējot jēdziena valodniecisko nozìmi, var konstatēt, ka operatīvā eksperimenta prettiesiskā izpausme var izpausties arī ārpus jēdziena "kūdīt" vēstījuma robežām. Piemēram, situācijās, kad operatīvais eksperiments tiek veikts bez atbilstoša pamatojuma, ierosinot noziedzīgu vai citādi prettiesisku rīcību izraisošu situāciju pret nekonkrētu personu loku $[12,60,61]$.

Tiesību teorētiki un praktiki jau šobrīd operatīvā eksperimenta prettiesisko aktivitāti mēdz apzīmēt ar jēdzienu "provokācija", kas varētu būt skaidrojams ar jēdziena "kūdìt" ierobežoto vēstījumu. Termins "provokācija" tiek izmantots arī juridiskajā literatūrā un Eiropas Cilvēktiesību tiesas (ECT) spriedumos.

Tādēḷ šis jautājums ir jāpēta padziḷināti. Nepieciešams noskaidrot, kāds ir ODL 4. panta otrās daḷas principa ("veicot operatīvās darbības pasākumus, aizliegts [..] kūdìt personas uz noziedzīgu rīcību" [4]) regulējuma mērḳis. Jānoskaidro arī normas formulējumā izmantotā jēdziena "kūdīt" un juridiskajā literatūrā izmantotā jēdziena "provocēt" nozīme un tas, vai normā lietotais termins nodrošina regulējuma mērḳa sasniegšanu un vai jēdziens "provocēt" to nenodrošina efektīvāk.

Balstoties uz pētījuma gaitā gūtajiem secinājumiem, tiks izteikti priekšlikumi, kas pētìtā operatīvās darbības principa formulējumu pilnveidos.

\section{Darba mērķis, materiāls un metodes}

Pētījuma mērḳis ir noskaidrot, vai pašreiz ODL 4. panta otrajā daḷā noteiktā operatīvās darbības principa formulējums nodrošina regulējuma mērḳa sasniegšanu, kā arī, balstoties uz pētỉjuma secinājumiem, sniegt zinātniski pamatotus priekšlikumus normatīvā regulējuma pilnveidošanai. 
Mērḳa sasniegšanai izmantota vispārējā zinātniskā analīzes pētỉjuma metode un speciālās juridiskās pētījuma metodes - sistēmiskā un valodnieciskā (filologiiskā) tiesību normu interpretācijas (tulkošanas) metode.

Lietojot analīzes metodi, tika pētìts ECT spriedumu saturs un noskaidrots, kādas prettiesiskas izpausmes ir konstatētas operatīvā eksperimenta u. c. valstu analogu pasākumu gaitā. Tika noskaidrots, pēc kādiem kritērijiem noškiramas iestādes prettiesiskas darbības no tiesiskām darbībām.

Izmantojot sistēmiskās tiesību normu interpretācijas metodi, kopsakarā ar ECT spriedumu analīzes rezultātiem, tika noskaidrota pētītā principa nozīme un normas regulējuma mērḳis.

Lai noskaidrotu jēdziena "kūdīt" un "provocēt" valodniecisko nozìmi, tika veikta juridisko un vispārējo valodas terminu skaidrojošo vārdnīcu izpēte un tajās skaidroto jēdzienu analīze.

Ar valodnieciskās (filologiskās) tiesību normu interpretācijas metodes palīdzību, kopsakarā ar jēdzienu analīzes secinājumiem un secinājumiem par ECT agrāk konstatētajiem cilvēktiesību pārkāpumiem, tika noskaidrots, vai pētītais jēdziens nodrošina normas regulējuma mērḳa sasniegšanu. Balstoties uz analizzes rezultātiem, tika sniegts priekšlikums normatīvā regulējuma pilnveidei.

\section{Eiropas Cilvēktiesību tiesas spriedumu nozīme operatīvās darbības gaitā}

Slepeno izmeklēšanas metožu (undercover techniques) ${ }^{1}$ izmantošana iestāžu darbā ir tiesiska tad, ja iestādes to izpildē ievēro Cilvēka tiesību un pamatbrīvību aizsardzības konvencijā (turpmāk - Konvencija) noteiktās cilvēka pamattiesības un citus likumos reglamentētus nosacijjumus, kuri attiecināmi uz šo metožu lietošanu. Ar jēdzienu undercover techniques tiek izteikta slēpta tiesībsargājošās iestādes pārstāvja darbība ar personām, kuras tiek izmeklētas (novērotas) [19, 1568]. Slēptu metožu lietošana ir sevišķi sensitīva, jo persona, pret kuru šāda metode tiek lietota, to neapzinās, tādēḷ pastāv personas pamattiesību pārkāpuma risks.

Praksē pārkāpumi notiek, un to cēloṇi var būt dažādi, sākot no Konvencijas normu nepilnīgas interpretācijas un beidzot ar iestādes amatpersonu neprofesionalitāti. Pārkāpumus izskata ECT, un tās spriedumos var atrast šādu metožu izmantošanas vadlīnijas (atzinnas). Iestādēm ECT judikatūra ir nozīmīgs tiesību avots, jo tiesas spriedumu saturs tām lauj prognozēt, vai plānotās darbības atbildīs ECT noteiktajiem tiesiskuma principiem, t. i., vai plānotajās darbībās nav saskatāmas jau agrāk analizētas iestāžu darbības, kas ar tiesas spriedumu atzìtas par nepielaujamām.

1 Jēdziens undercover techniques lietots ECT spriedumos, lai raksturotu iestāžu slepenās izmeklēšanas metodes, kurās tiek izmantoti slepenie palīgi vai iestādes amatpersonas, kuras darbojas leǵendēti. 
Mārcis Grinciuns. Operatīvās darbības likuma 4. pantā lietotā

jēdziena "kūdìt" atbilstība regulējuma mērḳim

Tiesību pētnieks un praktiķis Kalvis Torgāns paudis, ka "judikatūra ir tiesas nolēmumos ietvertu atziṇu kopums par tiesību jautājumiem, uz kurām balstoties tiesa ir izlēmusi jautājumus par tiesību normas interpretāciju, piemērošanu noteiktos faktiskajos apstākḷos [..]" [21, 2-3]. Atbilstīgi šai atzinaiai konstatēju, ka saistībā ar slēptu metožu lietojumu ECT spriedumos pausta Konvencijas 6. panta pirmās daḷas interpretācija un iestāžu faktisko darbību analīze, kas noveda pie interpretētās Konvencijas normas pārkāpuma.

Šajā sakarā īpaši svarīga ir ECT lietas Bannikova v. Russia sprieduma 34. rindkopā ietvertā atziņa, ka tiesa nevar attaisnot (justify) pierādijumu izmantošanu, kurus policija ieguva kūdīšanas (incitement) rezultātā. To piel̦aujot, apsūdzētie tiktu pakḷauti riskam, ka vinuu lietās jau no paša sākuma tiem tiktu liegtas tiesības uz taisnīgu tiesu [8]. Tiesības uz taisnīgu tiesu aizsargā jau pieminētā Konvencijas 6. panta pirmā dalıa, kurā noteikts, ka "ikvienam ir tiesības [..] uz taisnīgu un atklātu lietas savlaicīgu izskatīšanu neatkarīgā un objektīvā, likumā noteiktā tiesā” [1]. Šādu atziṇu ECT guvusi, vērtējot slepeno metožu izmantošanu, kurā iesaistīti iestādes slepenie informatori vai iestādes amatpersonas, kuras darbojas legenendēti.

Latvijā slepenie izmeklēšanas pasākumi un to īstenošanas metodes noteiktas un regulētas ODL normās. Atbilstīgi likuma terminologijai šādas iestāžu aktivitātes Latvijas tiesību sistēmā tiek dēvētas par operatīvo darbību. Operatīvās darbības saturs sastāv no operatīvās darbības pasākumiem un to ìstenošanas metodēm [4].

Šeit pētìtais operatīvais eksperiments ir definēts ODL 15. pantā. Normā noteikts, ka "operatīvais eksperiments ir operatīvās darbības subjektu amatpersonu darbība, kuras mērḳis ir radīt noteiktus apstākḷus (situāciju), lai noskaidrotu [..] vai arī noteiktu šajos apstākḷos to personu, attiecībā uz kurām tiek veikta operatīvā izstrāde, rīcību [..] un noskaidrotu šo personu rīcības motivāciju (subjektīvo pusi)" [4]. Tātad operatīvā eksperimenta izpausme vienmēr ir noteiktu apstākḷ radīšana. ODL 15. panta trešajā daḷā noteiktā operatīvā eksperimenta veida mērḳis ir "fiksēt, kā noziedzīgu vai citādi prettiesisku rīcību izraisošā situācijā rīkojas personas, attiecībā uz kurām tiek veikta operatīvā izstrāde" [4]. ODL 15. panta trešās daḷas noteiktā operatīvā eksperimenta radāmie apstākḷi ir noziedzịgu vai citādu prettiesisku rīcību izraisoša situācija. Šāds operatīvais eksperiments veicams, pamatojoties uz operatīvās darbības subjekta amatpersonas lēmumu, ko akceptējis prokurors [4]. Operatīvā eksperimenta laikā radītie apstākḷi var aizskart cilvēka pamattiesības, t. i., iespējama Konvencijas 6. pantā noteikto tiesību pārkāpšana, tāpēc pasākumam noteikta papildu kontrole - prokurora akcepts.

Operatīvā eksperimenta izpilde vienmēr notiek ar iestādei uzticamu personu starpniecību. Personas var būt iestādes slepenie palīgi vai speciāli apmācīti iestādes darbinieki. Šìs personas komunikācijā ar iestādi interesējošām personām vienmēr darbojas legendēti, un tieši tādēl operatīvā eksperimenta izpildes forma atbilst ECT uzskatam par to, kas ir slepena izmeklēšanas metode. 
Mārcis Grinciuns. Operatīvās darbības likuma 4. pantā lietotā

jēdziena "kūdìt" atbilstība regulējuma mērḳim

\section{Eiropas Cilvēktiesību tiesas spriedumu analīze: operatīvās darbības pasākumu prettiesiskās izpausmes}

Lai uzskatāmi atklātu ECT noteiktos slepeno izmeklēšanas metožu izmantošanas principus un tiesiskuma vērtēšanas kritērijus, kā arī atklātu pētìtā jēdziena "kūdīt" atbilstību vai neatbilstîbu normas regulējuma mērḳim, operatīvā eksperimenta norise jāanalizē tā izpildes posmos.

Operatīvā eksperimenta norisi var iedalīt divos posmos - sagatavošanās un pasākuma veikšanas aktīvajā posmā.

Sagatavošanās posmā darbinieks apkopo informāciju, kas pamato konkrētā pasākuma nepieciešamību, veicamās darbības un mērḳi. Informācijas kopums tiek atspogulots pasākuma dokumentācijā. Šāds nosacījums paredzēts ODL 23. ${ }^{1}$ pantā.

ODL 15. panta trešajā daḷā noteikts, ka operatīvais eksperiments jāīsteno tikai pret personām, attiecībā uz kurām tiek veikta operatīvā izstrāde. Savukārt izstrādes ierosināšanas nosacījums atrodams ODL 22. panta pirmajā dạ̦ā: operatīvo izstrādi var uzsākt gadījumos, ja "operatīvās darbības subjekta rīcībā ir informācija par konkrētām personām [..] un tā dod pietiekamu pamatu turēt šîs personas aizdomās par noziedzīga nodarījuma gatavošanu vai izdarǐ̌sanu [..]". [4]

Izstrādes ierosināšana likumā ir skaidri pamatota. Tiek secināts, ka pasākuma veikšanas pamatojums ir informācija par izstrādē esošās personas noziedzīgajām aktivitātēm un lietā fiksētie faktiskie izmeklētā gadījuma apstākḷi.

Slepenu izmeklēšanas metožu izmantošanu nedrīkst pamatot ar baumām. Šāds nosacijums pausts ECT lietas Ramanauskas v. Lithuania sprieduma 67. rindkopā [7]. Par baumām uzskatāma jebkura informācija, kas iegūta no konfidenciāliem avotiem un kura nav pārbaudìta. Tikai pēc informācijas pārbaudes var konstatēt, vai tā atbilst patiesībai un norāda uz noziedzīgām personas aktivitātēm.

Lai arī operatīvās izstrādes ierosināšana ir skaidri pamatota (ODL 22. panta pirmajā daḷā), tomēr praksē aktuāls ir jautājums par kritērijiem, pēc kuriem vērtēt pamatojuma pietiekamību un tajā ieklautās informācijas ticamību. Tas, ka pasākums tiek pamatots ar informāciju, kas norāda uz noziedzīgām personas aktivitātēm, vēl nenozīmē, ka šie fakti ir patiesi. Operatīvās darbības gaitā informācija bieži vien tiek iegūta no slepenajiem palīgiem, un daudzkārt šādas informācijas pārbaude ir ierobežota. Turklāt slepeno palīgu sniegtās ziṇas ne vienmēr ir patiesas.

ECT lietas Baltiňš pret Latviju sprieduma 56. rindkopā teikts, ka materiāla izvērtēšanas gaitā ECT noskaidroja, vai izmeklēšanas iestādēm bija pietiekams pamats turēt personu aizdomās par iepriekšēju iesaistī̌sanos konkrētās noziedzīgās darbībās. Tāpat tika vērtēts, kurā noziedzīgā nodarījuma posmā policijas slepenie aǵenti (vai informatori) veica operatīvo darbību [10]. Svarīgi konstatēt, vai iestāde pievienojās personas noziedzīgajai darbībai vai to iniciēja. Tas apliecina, ka pasākuma veikšanas pamatojumā iekḷautajai informācijai ir būtiska nozīme tā tiesiskuma vērtēšanā. 
Mārcis Grinciuns. Operatīvās darbības likuma 4. pantā lietotā

jēdziena "kūdìt" atbilstība regulējuma mērḳim

Skaidrojums, kādēl tas ir tik būtiski, meklējams ECT lietas Khudobin v. Russia sprieduma 49. un 134. rindkopā. Spriedumā teikts, ka iesniedzējs (Khudobin) pirms aizturēšanas iepriekš nav sodīts. Vienīgā informācija, kas liecināja par iesniedzēja saistību ar narkotisko vielu izplatǐšanu, saṇemta no policijas slepenās informatores. Tiesā liecību sniegšanas laikā šì informatore liecināja: "Tajā laikā es nezināju, kur iegūt heroīnu, tāpēc toreiz es izlēmu zvanìt Khudobin, jo agrāk viňš man tās bija sagādājis." No minētā ECT secināja, ka iesniedzējs nav policijai zināms narkotiku tirgotājs un policijas operācija netika vērsta konkrēti pret iesniedzēju, bet gan pret jebkuru personu, kas piekristu informatorei piegādāt heroīnu. [6]

Tātad, ja pasākuma pamatojuma dokumentācijā nav pārbaudītas informācijas, kas norāda uz noziedzīgām personas aktivitātēm, tiesai nekas cits neatliek kā secināt, ka līdz iestādes iejaukšanās brīdim persona ar konkrēto noziegumu nav bijusi saistīta.

ECT skatītajās lietās vērtē, vai noziedzịgais nodarījums tiktu izdarīts arī bez iestāžu iejaukšanās [10]. Vērtējot analizēto gadījumu no šī viedokḷa, ir skaidrs, ka tiesai nebija pamata uzskatît, ka persona noziegumu būtu izdarījusi arī bez iestādes iejaukšanās.

Khudobin v. Russia gadījums atklāj vēl citu nozīmīgu ECT principu - aizliegumu izmantot slepenas izmeklēšanas metodes (t. sk. operatīvo eksperimentu) pret nekonkrētu personu loku. Ja operatīvā darbïba tiek veikta bez objektīva un konkrēta pamatojuma, tas nozīmē, ka jebkurš cilvēks var kḷūt par iestādes mērḳi un pret vinu var tikt izmantotas operatīvās darbības subjekta rīcībā esošās ekskluzīvās operatīvās darbības metodes, taktika un speciālās tehnikas iespējas. Šāda rīcība demokrātiskā sabiedrībā nav piel̦aujama. Apskatītajā ECT spriedumā iestādes pamatojums bija pārāk vispārīgs - "notvert narkotiku tirgotāju", tādēl pasākums tika vērtēts kā veikts pret nekonkrētu personu loku [11, 61].

Operatīvā eksperimenta sagatavošanās posms noslēdzas ar pasākuma akcepta iegūšanu, un pēc tam tiek radīta noziedzīgu vai citādi prettiesisku rīcību izraisoša situācija.

No operatīvā eksperimenta sagatavošanās posma analīzes secināms, ka pasākums var iegūt prettiesisku ievirzi jau brīdī, kad tiek saṇemts tā akcepts. Pēc akcepta saņemšanas pasākuma gaitā tiks radīta noziedzīgu vai citādi prettiesisku rīcību izraisoša situācija, respektīvi, operatīvā eksperimenta veicējs sarunā ar izstrādē esošo personu var izteikt piedāvājumu, kas šĩs personas apziņā var ierosināt domas par noteiktu noziedzīgu rīcību, un izveidojas situācija, kad personai ir jāreageê, jāpauž kāds viedoklis (piemēram, pieņemt piedāvājumu vai atteikties). Ja iepriekš nav gūts apstiprinājums par personas noziedzīgo darbību, šāda domu ierosināšana, neapšaubāmi, ir provokatīva. Šãdā veidā uz pārbaudi var izaicināt jebkuru sabiedrības locekli, taču to aizliedz ECT princips par slēptu izmeklēšanas metožu lietošanu pret nekonkrētu personu loku. Pat ja operatīvā eksperimenta veicējs pasākuma izpildes gaitā nav kūdỉjis personu veikt noziedzīgas darbības, t. i., nav izdarījis nedz psihologisku, nedz fizisku spiedienu, nedz solījis kādus labumus, pasākuma izpilde tik un tā ir prettiesiska.

Kūdīšana jēdziena "kūdīt" izpratnē var izpausties tikai operatīvā eksperimenta izpildes aktīvajā posmā jeb fāzē, kad operatīvā eksperimenta veicējs izstrādē esošo personu var ietekmēt tiešā veidā, pierunājot vai piespiežot to veikt noziedzīgas darbības, 
taču provokācija uz noziedzīgu rīcību var izpausties jau tajā brīdī, kad šāda situācija tiek ierosināta. Situācijas izveide ir jānošḳir no operatīvā eksperimenta īstenotāja komunikācijas ar izstrādāto personu.

Pasākuma veikšanas aktīvajā fāzē operatīvā eksperimenta veicējs ar personu, kas atrodas izstrādē, nodibina kontaktu. Ja kontakts jau ir nodibināts, eksperimenta veicējs uzsākto komunikāciju turpina. Komunikācijas laikā viṇš ir tiesīgs ievirzìt sarunu par jautājumiem, kas saistīti ar izstrādē esošās personas noziedzīgo aktivitāti. Komunikācijas laikā operatīvā eksperimenta īstenotājs nedrīkst veikt darbības, kas personu var papildus motivēt, lai izdarītu noziegumu. ECT noteic, ka komunikācijai jānorit "pasīvā manierē".

Pasīvas izmeklēšanas princips ir definēts lietas Bannikova v. Russia sprieduma 47. rindkopā, kurā noteikta "līnija" starp likumīgu slepenā aǵenta iefiltrēšanu un pamudinājumu uz nozieguma izdarǐšanu. Iestādes atteikšanās no izmeklēšanas pasīvā veidā ir interpretējama situācijā, ja iestāde izrāda iniciatīvu sazināties ar personu, atjaunojot piedāvājumu, par spīti sākotnējam atteikumam, kā arī situācijās, ja tiek izteikts nepārprotams pamudinājums, arī cenas (un narkotisko vielu apjoma) paaugstināšana, kas pārsniedz vidējo, vai apelējot pie iesniedzēja līdzjūtības (žèluma) [8].

Interesants piemērs atrodams lietas Vanyan v. Russia sprieduma 11. rindkopā. Spriedumā teikts, ka policijas informatore zvanījusi iesniedzējam (Vanyan) un lūgusi vinai nopirkt narkotikas, piebilstot, ka viṇa cieš no neizturamām paǵirām (abstinences sindroma). Noraizējies, ka zvanìtāja varētu izdarīt pašnāvību, iesniedzējs piekrita satikties ar informatori netālu no viņam zināmā narkotiku izplatītāja mītnes, kurš iesniedzējam solījis narkotikas pārdot [5]. Šādas situācijas radīšana neatbilst ECT pasīvas izmeklēšanas principam, jo izraisītie apstākḷi personu būtiski ietekmēja. Persona tika nostādìta psihologiski neērtā situācijā, kas to motivēja veikt noziedzịgas aktivitātes.

Līdzīga situācija aprakstīta ECT lietas Veselov and others v. Russia sprieduma 20. rindkopā. Spriedumā teikts, ka informatore sazinājās ar iesniedzēju un piedāvāja tam atdot parādu (6000 rubḷu), kas bija radies iepriekšējo kontaktu laikā, taču piebilda, ka to darīs tikai tad, ja iesniedzējs viṇas vajadzībām sagādās heroīnu [9]. ECT policijas un informatores rīcībā konstatēja tādus apstākḷus, kas papildus motivēja personu veikt noziedzīgas aktivitātes. Arī šajā gadījumā policijas rīcībā pirms informatores vēstījuma nebija ziņu par personas saistîbu ar narkotisko vielu iegādi vai izplatǐšanu.

ECT lietu piemēri apstiprina iepriekš pausto uzskatu, ka personas kūdīšana var izpausties tikai operatīvā eksperimenta izpildes aktīvajā fāzē, kad operatīvā eksperimenta veicējs tiešā veidā sazinās ar izstrādē esošo personu. Taču, lai secinātu, vai normā lietotais jēdziens "kūdīt" sasniedz normas regulējuma mērḳi, ir jānoskaidro pētītā principa nozīme un regulējuma mērḳis. 
Mārcis Grinciuns. Operatīvās darbības likuma 4. pantā lietotā

jēdziena "kūdìt" atbilstība regulējuma mērḳim

\section{Operatīvās darbības likuma 4. panta otrajā daḷā noteiktā principa (regulējuma) mērḳis}

ODL 4. panta otrajā daḷā noteiktais kūdīšanas aizlieguma princips ir atvasināts no ODL 4. panta pirmajā daḷā noteiktā personu pamattiesību ievērošanas principa. Tas ir secināts, veicot ODL 4. panta pirmās dal̦as principa interpretāciju ar sistēmiskās tiesību normu interpretācijas (tulkošanas) metodes palīdzību. Lietojot šo metodi, tika analizētas Konvencijas, Satversmes un ODL normas.

ODL 4. panta pirmajā daḷā ir noteikts, ka "operatīvā darbỉba organizējama un veicama, pamatojoties uz likumïbu un ievērojot personu pamattiesības" [4]. Jēdziens "personu pamattiesības" ir jāsaista ar Satversmes astotajā nodaḷā noteiktajām cilvēka pamattiesībām, jo jēdzieni saskan gan vārdiski, gan pēc normu regulējuma mērḳa.

Jēdziens "personu pamattiesības" ODL saturā tika ieviests ar likuma grozijumiem 2016. gada 1. augustā. Iepriekš regulējumā tika izmantoti jēdzieni "vispārējās cilvēka tiesības" un "konstitucionālās tiesības". Tā kā likumprojekta anotācijā grozijumu izstrāde tika pamatota ar mērḳi nodrošināt augstāku cilvēktiesību ievērošanu operatīvās darbības procesā [17], var secināt, ka jēdzienu izmaiṇas notikušas, lai saistītajos likumos nodrošinātu vienveidīgu terminu lietojumu. Respektīvi, ODL terminologiija tika pielāgota cilvēktiesības reglamentējošam likumam - Satversmes astotajai nodaḷai (Cilvēka pamattiesības).

Kontekstā ar pētīto ODL 4. panta pirmajā dalıā ietverto personu pamattiesību ievērošanas principu, jāizcel̦ Satversmes 92. pantā noteiktās cilvēka pamattiesības: "Ikviens var aizstāvēt savas tiesības un likumiskās intereses taisnīgā tiesā” [3]. Pēc būtības līdzīgs vēstỉjums ietverts arī Konvencijas 6. panta pirmajā dạ̦ā noteiktajās cilvēktiesībās: "Ikvienam ir tiesības [..] uz taisnīgu un atklātu lietas savlaicīgu izskatīšanu neatkarīgā un objektīvā likumā noteiktā tiesā” [1]. Savukārt ar Konvencijas 6. pantā noteiktajām personu tiesībām rakstā tika skaidrots iemesls, kādẹl iestāžu darbā nav piel̦aujama personas kūdišana. Respektīvi, tiesa nevar attaisnot pierādījumu izmantošanu, ja tie iegūti policijas īstenotas kūdīšanas rezultātā [8].

Pamatojoties uz šādu normu interpretāciju, var secināt, ka pastāv tieša sakarība starp ODL 4. panta pirmajā dal̦ā noteikto personu pamattiesību ievērošanas principu un pētìto ODL 4. panta otrajā daḷā noteikto kūdišanas aizlieguma principu. Kūdīšanas aizliegums normā nav definēts kā cilvēka pamattiesību aizsardzības noteikums, taču tas izriet no normu interpretācijas un ECT spriedumu analizzes. Abos principos paredzēta cilvēka pamattiesību ievērošana. ODL 4. panta pirmajā dạ̣ā noteiktajā principā paredzēts arī kūdīšanas aizliegums, jo kūdī̌ana uz noziegumu ir cilvēka pamattiesību pārkāpums. Var secināt, ka likumdevējs kūdǐšanas izpausmi kā aizliedzošu darbỉbu likumā ir vēlējies īpaši izcelt, tādēl regulējumā ietverts skaidrs aizliedzošās darbības definējums - "aizliegts kūdìt".

Tiesību normu interpretācijas rezultātā secināts, ka pētītā principa regulējuma mērḳis ir nodrošināt cilvēka pamattiesību ievērošanu. Turpmāk pētījuma gaitā tiks noskaidrots, vai regulējuma formulējums to nodrošina. Nepieciešams veikt padzilininātu jēdziena "kūdīt" un "provocēt" valodnieciskās nozīmes analīzi un rezultātus salīdzināt ar ODL 4. panta otrās daḷas regulējuma mērḳa vēstỉjumu. 
Mārcis Grinciuns. Operatīvās darbības likuma 4. pantā lietotā

jēdziena "kūdìt" atbilstība regulējuma mērḳim

\section{Jēdzienu "kūdīt" un "provocēt" valodnieciskās jēgas analīze kopsakarā ar Operatīvās darbības likuma 4. panta otrajā daḷā noteiktā principa regulējuma mērḳi}

Šajā pētījumā tiks noskaidrots, vai jēdziena "kūdīt" valodnieciskā nozīme atbilst iepriekš aprakstītajām operatīvā eksperimenta prettiesiskajām izpausmes formām, vai jēdziens nodrošina regulējuma mērḳa sasniegšanu. Normā lietotā jēdziena atbilstîba aizliedzošajām darbībām tika izpētīta, lietojot valodniecisko (filologisko) tiesību normu interpretācijas metodi kopsakarā ar iepriekš noskaidroto principa regulējuma mērkị.

Latviešu literārās valodas vārdnīcā jēdziens "kūdīt" skaidrots kā "rosināt, mudināt uz kādu (parasti neatḷautu, negodīgu) rīcību" [15, 461]. Savukārt izklāstā ietilpstošais jēdziens "rosināt" tiek skaidrots kā "censties padarìt (kādu) rosīgu, aktīvu; censties panākt, ka sākas (darbība, rīcība)", bet jēdziena "mudināt" nozīme ir "ar savu runu, arī žestu, izturēšanos u. tml. censties panākt, lai (kāds) ko dara" [20].

Var secināt, ka jēdziena skaidrojums atbilst ECT noteiktajiem pārkāpumiem, kuri izpaužas operatīvā eksperimenta aktīvajā fāzē, t. i., kad operatīvā eksperimenta veicējs izstrādē esošo personu ietekmē (mudina) ar savu attieksmi, runu u. c. darbībām. Jēdzienu nevar attiecināt uz pārkāpumiem, kuri izpaužas operatīvā eksperimenta sagatavošanās posmā un izpildās brīdī, kad tiek ierosināta noziedzīga vai citādu prettiesisku rīcību izraisoša situācija. Situācijas ierosināšana pati par sevi ir pārkāpums, un nav svarīgi, vai operatīvā eksperimenta veicējs vēl kā citādi ietekmēs izstrādē esošo personu.

Rakstā tiek pētīti juridiskie jautājumi, tādēl ir jāaplūko arī juridisko terminu vārdnīcās iekḷautie jēdzienu skaidrojumi. Juridisko terminu vārdnīcā jēdziens "kūdīt" ietverts zem jēdziena "uzkūdīšana" skaidrojuma un tas ir šāds: "Uzkūdīšana nozīmē kādas personas fizisku vai psihisku ietekmēšanu, kas vērsta uz to, lai citā personā radītu apñemšanos izdarìt noziedzīgu nodarījumu vai piedalīties tajā. Uzkūdītājs ir persona, kura pamudinājusi citu personu izdarīt noziedzīgu nodarījumu" [13, 126, 276]. Tātad tā ir fiziska vai psihologiska ietekmēšana, kuras rezultātā personai rodas vēlme izdarìt noziegumu. Uzskatu, ka cilvēka apn,emšanos veikt kādu darbību var panākt tikai ar tās iespaidošanu (to motivējot), taču noziedzīgas vai citādi prettiesiskas situācijas ierosināšana nav saistāma ar pašas personas apṇemšanos. Radītās situācijas laikā personai joprojām ir brīvas izvēles iespējas, taču situācijas (prettiesiskais) raksturs personas apziṇai liek domāt par izšķiršanos starp noziedzīgu aktivitāti vai atteikšanos no tās.

Krimināltiesību izpratnē uzkūditāja loma izpaužas tādējādi, ka uzkūdītājam rodas doma par nodarījuma izdarǐšanu, bet noziedzīgā nodoma realizēšanai viņš izvēlas citu personu, un ar tās palīdzību tiek izdarìts noziedzīgs nodarījums [14, 107].

Vērtējot krimināltiesību teorētiḳu skaidrojumu par uzkūdītāja lomu nozieguma izdarī̌anā kontekstā ar šeit pētīto kūdīšanas aizliegumu, var secināt, ka operatīvā eksperimenta veicēja aktivitāte nekādā ziṇā nav saistāma ar noziedzīga nodoma realizāciju. ODL lietotā jēdziena nozīme ir būtiski atšḳirīga no Krimināllikuma 20. panta trešajā dạ̦ā lietotā jēdziena vēstījuma. Krimināllikumā jēdziens "uzkūdītājs" tiek izmantots nozieguma 
Mārcis Grinciuns. Operatīvās darbības likuma 4. pantā lietotā

jēdziena "kūdìt" atbilstība regulējuma mērḳim

līdzdalības formas definēšanai: "par uzkūdītāju uzskatāma persona, kas pamudinājusi citu personu izdarīt noziedzīgu nodarījumu" [2], savukārt ODL lietotais jēdziens "kūdìt" nosaka iestādes aizliedzošu rīcību operatīvās darbības ietvaros. Taču, vērtējot uzkūdītāja aktivitātes no operatīvā eksperimenta veicēja aspekta, var secināt, ka kūdīšana izpaužas tikai situācijā, kad persona (kūdìtājs) aktīvi iespaido otras personas rīcību. Šāda jēdziena analīze norāda uz iepriekš pausto secinājumu, ka kūdī̌ana izpaužas tikai situācijās, kad persona aktīvi pierunā citu veikt noziegumu.

Tas nozīmē, ka operatīvā eksperimenta laikā prettiesiskā darbỉba var izpausties arī ārpus kūdīšanas jēdziena robežām. Tādēḷ nepieciešams saprast, vai jēdziena "provocēt" skaidrojums ietver tās aizliedzošo darbību pazīmes, kas izpaužas operatīvā eksperimenta sagatavošanās posmā un brīdī, kad tiek ierosināta noziedzīga vai citādu prettiesisku rīcību izraisoša situācija.

Latviešu literārās valodas vārdnīcā jēdziens "provocēt" skaidrots kā "nodevīgā, negodīgā, arī izspiegošanas nolūkā izaicināt, musināt, kūdīt (kādu veikt kādu darbību), lai (tam) kaitētu; nodevīgā, negodīgā, arī izspiegošanas nolūkā izraisìt (kādu darbību), lai kaitētu (tās) veicējam; tīši izraisìt nevēlamu personīgu situāciju (kādam); izraisīt" $[16,413]$. Savukārt jēdziens "izaicināt" tiek skaidrots kā "aicinot panākt, ka (kāds) iznāk (no kurienes, kur u. tml.); ierosināt (ko darît); ierosināt (uz ko); izraisīt (norisi, stāvokli)", bet jēdziens "izraisìt" - kā "panākt, būt par cēloni, ka rodas, izveidojas (psihisks vai fiziologisks stāvoklis, tā izpausme)" [20].

Latviešu literārās valodas vārdnīcās jēdziena "provocēt" skaidrošanai tiek izmantoti darbības vārdi "izaicināt", "izraisīt" un "musināt", kas būtībā ietver plašāku apstākḷu izpildīšanos, ne tikai personas pierunāšanu vai mudināšanu veikt noziegumu. Acīmredzot jēdziena "provocēt" būtība ir plašāka nekā jēdziena "kūdīt" nozīme.

Juridisko terminu vārdnīcā jēdziens "provokācija" tiek skaidrots kā "atsevišḳu personu [..] negodīgā, nodevīgā ceḷā organizēta uzkūdīšana, uzaicināšana, musināšana izdarīt darbības, kas tiem rada smagas sekas; parasti ir orientēta tā, lai kaitētu tās veicējam tiem nevēlamas situācijas tīša izraisǐšana" $[13,219]$. Jākonstatē, ka jēdziens "uzkūdīt" tiek nosaukts kā viens no jēdziena "provocēt" izpausmes veidiem. Taču jāizceḷ, ka termina skaidrojumā provokācija tiek raksturota kā nevēlamas situācijas tī̌̌a izraisīšana, kas saskan ar operatīvajā eksperimentā radīto noziedzīgu vai citādi prettiesisku rīcību izraisošu situāciju.

No jēdzienu literārā skaidrojuma skatpunkta raugoties, jēdziens "kūdìt" nozīmē personas pierunāšanu uz kādu negodīgu rīcību. Savukārt jēdziens "provocēt" nozīmē arī "izraisīt (kādu darbību), lai kaitētu (tās) veicējam" un "nevēlamas situācijas tī̌̌u izraisīšanu", kas saskan ar operatīvā eksperimenta pārkāpumu raksturu tā sagatavošanas posmā, un likumsakarīgi tiek ierosināta prettiesiska noziedzīgu rīcību izraisoša situācija. Kā tika noskaidrots iepriekš, operatīvā eksperimenta gaitā tiek radīta noziedzīga vai citādi prettiesisku rīcību izraisoša situācija. Ja persona operatīvā eksperimenta gaitā radīto apstākḷu (ierosinājuma) dēl izšḳiras veikt noziedzīgas darbības, personas (noziedzīgā) rīcība pēc operatīvā eksperimenta noslēguma tai kaitē. 
Secināms, ka jēdziena "provocēt" valodnieciskais skaidrojums saskan ar pārkāpuma raksturu, kas izpaužas operatīvā eksperimenta sagatavošanas posmā un izpildās, iestādei ierosinot noziedzīgu vai citādi prettiesisku rīcību izraisošu situāciju. Turpretī jēdziena "provocēt" būtība ir plašāka nekā jēdziena "kūdīt" saturs. Provokatīvu darbību skaidrojumā tiek iekḷauta arī kūdǐšanas izpausme, kas nozīmē to, ka jēdziens "kūdìt" ir aizstājams.

N̦emot vērā, ka no jēdziena "kūdīt" atvasinātais jēdziens "uzkūdītājs" tiek izmantots krimināltiesībās un tam tiesību sistēmā ir cita - daudz šaurāka - nozīme, "kūdīt" lietojums ODL normās jēezienu skaidrības dēḷ nav vēlams.

\section{Secinājumi un priekšlikumi}

Balstoties uz pētījuma gaitā gūto secinājumu, ka Operatīvās darbības likuma 4. panta otrajā daḷā noteiktā kūdīšanas aizlieguma principa regulējuma mērkis ir cilvēka pamattiesību aizsardzība, konstatēts, ka aktuālais panta formulējums nenodrošina pilnvērtīgu normas mērḳa sasniegšanu. Jēdziena "kūdīt" valodnieciskais vēstījums neaptver visas prettiesiskās izpausmes, kuras var izpausties operatīvā eksperimenta izpildē.

N̦emot vērā pētījumā gūtos secinājumus, Operatīvās darbỉbas likuma 4. panta otrās daḷas regulējumā iekḷautais vārds "kūdìt" jāaizstāj ar vārdu "provocēt".

\section{The Term "Incite", Used in Section 4 of the Operational Activities Law, Compliance with the Regulatory Objective}

\section{Abstract}

Operational activities law (hereinafter - ODL) of the Republic of Latvia Section 4 defines the principles of operational activity to be observed during the planning and execution of operational activities. The principle laid down in paragraph two of the Section 4 provides the prohibition of incitement to criminal acts. The prohibition of incitement shall also apply to the conduct of the operational measure "Investigatory Experiment", as the performer of the measure may instigate (incite) criminal activities in contact with the person of interest. Incitement during investigatory experiment is illegal, and that has been confirmed both in the judgments of the Supreme Court of the Republic of Latvia and in the judgments of the European Court of Human Rights.

In previous studies, the author has found that inciting a person (encouraging) to commit a crime is only one of several forms of illegal expression of an investigatory experiment. The author of the Paper believes that apart from incitement, a person may also be provoked to commit a crime. 
Mārcis Grinciuns. Operatīvās darbības likuma 4. pantā lietotā

jēdziena "kūdìt" atbilstība regulējuma mērḳim

In the framework of the article, in the context of alleged breaches of the investigatory experiment in practice, the current article analyses the meaning of the term "inciting" and concludes whether this term has reached the regulation purpose of the ODL Article 4.

Keywords: operational activities, operational measure, principles of operational activities, operational experiment, investigatory experiment, test purchase, entrapment, incitement, provocation.

\section{Avoti un literatūra}

\section{Tiesību akti}

1. Cilvēka tiesību un pamatbrīvību aizsardzības konvencija: starptautiska konvencija. Latvijas Vèstnesis. 143/144 (858/859), 13.06.1997.

2. Krimināllikums: Latvijas Republikas likums. Latvijas Vēstnesis. 199/200(1260/1261), 08.07.1998.

3. Latvijas Republikas Satversme: Latvijas valsts likums. Valdības Vēstnesis. 141, 30.06.1922.

4. Operatīvās darbības likums: Latvijas Republikas likums. Latvijas Vēstnesis. 131, 30.12.1993.

\section{Tiesu prakse}

5. European Court of Human Rights: judgment of 15th March 2006: case of Vanyan v Russia, application No. 53203/99. Council of Europe. Iegūts no: https://ej.uz/ch9g [sk. 12.01.2019.].

6. European Court of Human Rights: judgment of 26th January 2007: case of Khudobin v Russia, application No. 59696/00. Council of Europe. Iegūts no: http://ej.uz/tpyc [sk. 12.01.2019.].

7. European Court of Human Rights: judgment of 5th February 2008: case of Ramanauskas v. Lithuania: application No. 74420/01. Council of Europe. Iegūts no: https:/ej.uz/wxea [sk. 27.04.2019.].

8. European Court of Human Rights: judgment of 4th February 2011: case of Bannikova v. Russia: application No. 18757/06. Council of Europe. Iegūts no: https://ej.uz/k5to [sk. 12.01.2019.].

9. European Court of Human Rights: judgment of 2nd January 2013: case of Veselov and others v. Russia: application No. 23200/10, 24009/07 and 556/10. Council of Europe. Iegūts no: https:// ej.uz/45hp [sk. 27.04.2019.].

10. European Court of Human Rights: 2013. gada 8. janvāra spriedums lietā Baltiņš pret Latviju: iesniegums Nr. 25282/07. Council of Europe. Iegūts no: https://ej.uz/dfm1 [sk. 12.01.2019.].

\section{Literatūra}

11. Grinciuns, M. 2018. Operatīvā eksperimenta problemātika: maǵistra darbs. Rīga: Rīgas Stradiṇa universitāte.

12. Grinciuns, M. 2018. Operatīvā eksperimenta veikšanas nosacījuma izpildes problemātika. Socrates. 1(10). Iegūts no: https://ej.uz/ouz2 [sk. 20.01.2019.].

13. Juridisko terminu vārdnīca. 1998. Aut. kol. U. Krastiņš, I. Krastin̦š, V. Durbe, A. Fogels, I. Fridriksons, K. Torgāns u. c. Rīga: Nordik.

14. Krastiņš, U., Liholaja, V. 2015. Krimināllikuma komentāri. Pirmā daḷa (I-VIII ${ }^{1}$ nodaḷa). Rīga: Tiesu namu aǵentūra.

15. Latviešu literārās valodas vārdnīca. 4. sēj. J-L. 1980. Rīga: Zinātne.

16. Latviešu literārās valodas vārdnīca. 62. sēj. P-R. 1987. Rīga: Zinātne. 
17. Likumprojekts "Grozỉjumi operatīvās darbības likumā” sākotnējās ietekmes novērtējuma ziṇojums (anotācija). Nr. 90/TA-758. 2014. Latvijas Republikas Saeima. Iegūts no: https://ej.uz/nj81 [sk. 20.01.2019.].

18. Normatīvo aktu projektu izstrādes rokasgrāmata. 2016. Rīga: Valsts kanceleja sadarbībā ar Tieslietu ministriju, Labklājības ministriju un Ārlietu ministriju. Iegūts no: https://ej.uz/27f9 [sk. 02.02.2019.]

19. Oxford English Reference Dictionary. 2003. New York: Oxford University Press Inc.

20. Terminu skaidrojošā vārdnīca “Tēzaurs”. Iegūts no: http://www.tezaurs.lv/ [sk. 20.01.2019.].

21. Torgāns, K. Judikatūras teorija un pielietojamā judikatūra. Jurista Vārds. 2005, 47(402). 